\title{
Advancing Social Capital through Participatory Approaches Case of Community-Based Slum Upgrading in Yogyakarta,
} Indonesia

\author{
Muhammad Nelza Mulki Iqbal ${ }^{1}$ \\ ${ }^{1}$ Jurusan Arsitektur, Institut Teknologi Indonesia, Serpong, Indonesia \\ nelzamiqbal@gmail.com
}

\begin{abstract}
Social capital discourse has come to be the foremost and essential aspects in achieving sustainable development, participatory democracy and just cities. Indonesia is like most Asian countries where people spatially and socially co-live in a community that is related to a network of small clusters. However, the formal study related to social capital is hardly founded. Based on its characters, Gotong Royong which is a socio-cultural ethic of the togetherness philosophy in Indonesia can be perceived as an Indonesian social capital practice. Advancing social capital through participatory approaches will need a deep consideration about the role of professional and community engagement. Successful collaborations between wider actors in participatory approaches could lead to a fundamental transformation that can both preserve and nurture social capital values. High level of social capital within communities can potentially underpin the successful community participation towards communal goals.
\end{abstract}

Key words: Social Capital, Community, Participatory, Slum Upgrading, Gotong Royong

\begin{abstract}
Abstrak: Konsep tentang modal sosial muncul sebagai aspek utama dalam mencapai pembangunan berkelanjutan, demokrasi partisipatif, dan pembangunan kota yang adil. Indonesia seperti banyak negara di Asia, kebanyakan penduduknya hidup secara berkelompok dalam satu komunitas jaringan atau kelompok kecil. Namun studi formal tentang modal sosial di Indonesia masih sulit ditemui. Mengacu pada karakter dasarnya, Gotong Royong sebagai moral kultural-sosial dari nilai filosofis kebersamaan di Indonesia dapat diterjemahkan sebagai praktek modal sosial di Indonesia. Di lain sisi, meningkatkan potensi modal sosial melalui pendekatan partisipatif memerlukan pertimbangan mendalam terhadap peran professional dan keterlibatan komunitas. Kolaborasi efektif banyak aktor dalam pendekatan partisipatif akan membawa dampak transformatif yang dapat mempertahankan sekaligus meningkatkan nilai-nilai dari modal sosial. Kadar modal sosial yang tinggi diantara komunitas dapat mendukung kesuksesan partisipatif komunitas menuju tujuan-tujuan bersama.

Kata kunci : Modal Sosial, Komunitas, Partisipatif, Peningkatan Kawasan Kumuh, Gotong Royong
\end{abstract}

\section{INTRODUCTION}

Arguably the most popular dispute in the field of urban and city planning was a conflict between a legendary New York's city planner Robert Moses and an ordinary New York's citizen named Jane Jacobs in 1961. It was considered as an iconic representation of the tension between top-down representative and organic notions of citizen initiative in the twentieth century.
While Jacobs believe that beauty of diversity urban realm should be accommodated in order to achieve the city for everybody, Moses stood with a heavy-handed urban planning through a large-central intervention. Through her observation, Jacobs argued that central planning was failed to fulfil people needs in creating better city life. What city needs the most is embedded in its diversity, complexity, and disorganized ideas of 
the city that give each other mutual support [Jacobs, 1961].

Assuming that every part of the city should get their right to build city's future, she then emphasized that city's renewal and development is not just simply building parks and housing towers in express ways. Rather, she challenged the field of urbanism and sarcastically mentioned that planners should leave a single paradigm, what so called by radiant-gardenbeautiful, in the city planning. Building on the local views and perspective, she offered a tangible network within the well-connected urban neighborhood as a solution towards better city planning. Later on, we recognized Jacob's idea as social capital.

The key concern on the discourse of social capital will be based on the works of Pierre Bourdieu, Robert Putnam, and James Coleman. Referring Bourdieu's notion about social capital that could not be built in a short time, I will try to investigate Indonesian local belief of "Gotong Royong" and consider it as Indonesian social capital practice. Therefore, a comprehensive review about social capital discourse will be discussed in first chapter to get a clear understanding about social capital in general term.

The next chapter will further elaborate the use of participatory approaches in advancing social capital and how it relates to the community and professional involvement. The works of Community Architect in Yogyakarta, Indonesia (ArkomJogja) with the poor riverside communities (Paguyuban Kalijawi) will be discussed here to further investigate the social capital practice in Indonesian context. The conclusion will deduce that social capital should be well-considered as the base foundation of slum upgrading projects even it needs a meticulous consideration related to the role of time, people's habit, and regional context.

\section{THE METHODS}

The research is concerned on analyzing Gotong Royong which is a socio-cultural ethic of the togetherness philosophy in Indonesian society, and created an argumentation of using this term as Indonesian social capital practice. Together with these findings, it also contributes to simplify an advancement of social capital through participatory approaches that figures a case study in community slum upgrading in Yogyakarta, Indonesia. All those objectives are accomplished through two different stages

\section{Pre-fieldwork}

Before making a concluding thought about social capital practice in Indonesian context, it is important to make a clear perception about social capital discourse also a conception about community, professional practice, participatory approaches, and gotong royong. This paper is perhaps contributing in a solid foundation of social capital trajectories by highlighting some important aspects in social capital. Through an intensive literature review from related books, journals, reports and previous studies, the research is proposed to capture correlation between theories and real practice on the ground to further contribute in the social capital field debates.

\section{Fieldwork}

Fieldwork stage were conducted to make sure correlation between theories and real evidence in the field. It was also taken to get a primary data by a direct observation and in-depth interviews. Observation includes several areas where the communities (Paguyuban Kalijawi) and professional group organization (ArkomJogja) worked together especially along Gajahwong and Winongo riverside. In-depth interviews conducted by interviewing selected informants that come from both organizations.

\section{RESULT AND DISCUSSION}

\subsection{Revisiting Social Capital Discourse}

Social capital discourse has come to be the foremost and essential aspects in achieving sustainable development, participatory democracy and just cities. At least in the last decade, the remarkable resurgence of social dimensions in development and specifically about social capital is clearly visible [Woolcock, 2002].

Therefore, it is not coincidental when a lot of international organizations and agencies, like World Bank, are looking into this approach to help people in the development world withstands their urban crisis [World Bank, 2000; Hickey \& Mohan, 2004]. In recent decades, a lot of scholars have been involved in the discourse of social capital, how it can be used, measured, and more importantly its effects in the development context [Coleman, 1988; Putnam, 2000; 
Uphoff, 2000; Woolcock, 2001].

These are composed of a research result as displayed as words, tables, figure, and photographs. The limitation of using grapics and photos will be appreciated. However, it needs to be displayed if it can describe a better explanation for research result. All of Figures and tables should be given continuing numbers and must be referred in the article.

Referring back to the remarkable story about topdown and bottom up approaches in the field of urban design and planning, Jane Jacobs mentioned about citizen networks that should be accommodated in urban planning rather than a heavy-handed approach like what Robert Moses proposed for New York City. What city needs the most is embedded in its diversity, complexity, and disorganized ideas of the city that give each other mutual support [Jacobs , 1961]. What Jacobs strived for, later on, is known as social capital. A pivotal idea within this term is that a social network has a value. It refers to a collective value and communal tendency that awakens from beneficial aspect of networking to do communal things. Social capital promotes cooperative behaviors that would be valuable to individual benefits as well as community in larger impacts.

The key concern on social capital discourse in the contemporary context commonly proceeds from three key sources: the works of Pierre Bourdieu, Robert Putnam, and James Coleman. The French sociologist, Pierre Bourdieu was interested in the symbolic power of the class and how the stigma bounds up with forms of domination [Bourdieu, 1986]. Bourdieu saw class privilege to be tied up by having an access to what he referred as capital. Bourdieu's notions about capital were built upon the material theory in economical context. The three fundamental capitals in Bourdieu's notions include: economic capital, cultural capital, and social capital. The importance of social capital based on Bourdieu's notion is related to range of people's networks that can affect to their life chances. For Bourdieu, social capital is the accumulation of resources, visible or invisible, that grow personally or communally through the benefit of possession in a durable network of institutionalized relationships based on the sense of acknowledgement and familiarity [Bourdieu, 1986]. Therefore, social capital in
Bourdieu's notion tends to be assumed as a personal perspective towards its benefit. Additionally, the level of social capital relies on the quality and quantity of networking that has been created before. It is to say that being a part of communal group will be valuable due to its time possession of the communal capital.

The second notion about social capital is derived from Robert Putnam, an American political scientist. His seminal book on civic associations in Italy considers social capital as a value of social organizations such as networks, trust, and norms that working together to achieve mutual benefit [Putnam, 1993]. However, he explained that trust, norms, and networks are not a social capital per se, instead they are derived from the existence of social capital. Through a civic network, social capital can nurture norms of reciprocity that strengthens the level of trust within a society and improves its productivity and effectivity. Importantly, the feature of social capital has been further explored again by Putnam into two different forms: bonding and bridging social capital [Putnam, 2000]. Bonding social capital ties people in a similar fashion such as families, friends, ethnicities, religions, conditions, or even political views. Its existence reinforced what is already inside the community as a specific and homogenous group with similar characters. In contrast, bridging social capital ties outside networks that are farther distanced with different interests which are commonly defined as cross-cutting relations. By using the terminology of bonding and bridging social capital, Putnam posits social capital into a set of horizontal relationships based on society's connection and networks.

James Coleman broadens Putnam's definition about social capital by introducing a vertical aspect of social capital. Combining the horizontal and the vertical aspect of social capital, Coleman defines social capital as "a variety of different entities, with two elements in common: they all consist of same aspect of social structure, and facilitate certain actions of actors whether personal or corporate- within the structure" [Coleman, 1988]. Vertical associations are indicated by hierarchical relationships and an unequal distribution of power among members within the network. These relations can be either beneficial or harmful, depending on the characters, situation, condition, even a political 
will. Understanding vertical aspect of the social capital, Woolcock adds a third category of social capital to complete the three-tiered categorization of social capital: bridging, bonding, and linking social capital [Woolcock, 2001]. The function of linking social capital is to widely leveraging physical and non-physical matters that could not be proceeds by bridging and bonding social capital. In real urban setting, we can see the manifestation of vertical aspect as a linking capital from the government position, bonding capital can be taken from interconnection among group of people with similar purpose, and bridging capital refers to the relation of these communities in wider context to achieve more powerful goals.

Through an economic analysis, the standard category of capitals - physical, natural, and human - are now being added as well with a fourth, social [Serageldin, 1996]. The latter has been added because the three categories of capital partially determine a process of economic growth. In fact, we also need to consider how relations between the actors to generate more profound outcomes that goes beyond just physical benefits. Incorporating social capital in the field of urban design and city planning is exceptionally relevant and essential. It could be the core aspect of any possibility approaches in ensuring sustainable city development. Preserving social capital within society at least can ensure the continuity of project outcomes. However, understanding the role of time, people's habit, and regional context should be considered as the main principal before deciding to nurture social capital value within society.

\subsection{Participatory Approaches in Advancing Social Capital}

Participatory in the development context conventionally emerges as a critique of the failure in the top-down development approaches [Cooke \& Kothari, 2001]. It emerges due to ineffectively external imposed and expert-oriented forms of research and planning that have been criticized since the 1980s. The aim of the participatory approach is to make people central to the development by accommodating their involvement in the decision making that could affect to their future life. It intends to accommodate people's voice that was previously being excluded by the top- down approaches to provoke more appropriate and visible outcomes.

The top down approach led by the state or market often fails to meet and provide adequate goods and services to the whole society, especially for the urban poor. Therefore, alternative paradigms emerge that involves participatory, a bottom up approach, which considers development as a process initiation by and for people [Meribe, 2012]. In alignment to Jacobs's notion that "cities have the capacity of providing something for everybody, only because they are created by everyone" [Jacobs, 1961]. Participatory is, perhaps, incorporating people's agency based on their local knowledge, skills and priorities. Therefore, in the development context, participatory approach has been highlighted due to its relevance, empowerment, and sustainability [Cooke \& Kothari, 2001]. Through participatory approach, citizen is encouraged to be actively involved in developing their own destiny rather than just act as passive recipients of the development program.

Furthermore, participatory approaches will not only realize direct needs in terms of city development but also indirect benefits to the society. The direct needs that can be achieved through participatory approaches related to physical or spatial products that are often addressed by participatory design methodologies [Frediani \& Boano, 2012). It is Including people's views about their preferences related to proper techniques, materials, conditions, priorities, and it is helpful to achieve suitable outcomes. Indirect aspects of participatory linked to social benefits that can be improved through engagement processes of participation. Therefore, citizen participation has been considered as a necessary component in the participatory approach for the development context. Involving people in the process of design as well as project implementation is more expected to ensure the long-term sustainability of project outcomes [Archer, 2009].

The main potential of participation is when it goes beyond just a product and consensus, but it also enables exercising possibility through a sense of "dissensus" [Boano \& Kelling, 2013]. As a practice of incorporating diversity in participation, participatory approach should be able to be a discursive practice 
from well-laid and fixed plans to be more adaptable and flexible. Therefore, participatory practice is usually concerning on the progress of planning rather than pushing fixed physical outcomes. By not requiring specific physical output, participatory approach in the context of development allows the community to lead their own development [Boano \& Kelling, 2013]. The flexibility aspect of the approach gives people the choice to decide their pathway solutions based on their own characters.

The nature concept of participatory and social capital has similar impetus. A lot of evidences indicate that project implementations without considering human dimensions in terms of norms, trust, solidarity, and reciprocity will be less successful. Furthermore, participatory is considered as an important method in increasing the existence of social capital. Participatory can be used to empower people to take over the development process by having a sense of control over their own future [Colletta \& Cullen, 2000]. It liberates development process to be more bottom-up and demand-driven rather than top-down and supply-driven which is harshly criticized by a lot of scholars.

As the foundation of the participatory approaches, social capital has permeated to nurture a rich network of cross-cutting society whether it is applied through formal or informal institutions. Moreover, there is a high level of attention between formal and informal terms in participatory approaches discourse. Participatory are influenced by the new institutionalism that allows communities to have a formal mechanism of mutual cooperation as well as exercising sanctions [Cleaver, 2001]. Some scholars argue that formal institutions (most commonly conceptualized as organizations) are helpful to obtain visible participation and to render the legible community from individual interests into collective endeavors [Scott, 1998]. However, considering the fact that many interactions between people also take place outside formal organizations, shaping cooperation is more important than just focusing to form a formal organization. Following the term of bridging and linking social capital, shaping cooperation that is not just focusing on internal relation could attract more stakeholders in creating a massive collaboration.

\subsection{Community Notion towards Participatory}

In terms of social capital, household networks and community associations also become the most prominent evidence to show how we can see the nature of civic participation and its operations in exchanging communal benefits [Woolcock, 2001]. Taking this tied community networks into account, social capital which is applied in the community associations can help people get a lot of benefits especially economic benefits- such as better incomes, preferable working positions, efficient working tasks, and longer lives [Woolcock, 2001].

Understanding the sense of community is not only relevant but also important before incorporating community into participatory approaches. Butcher identifies the three interrelated senses of the community: descriptive community, community as a value, and active community [Butcher, 1993]. The descriptive community related to how the community can be built, and it can be varied from just a geographical context to personal interests. As the basic sense of the community, it somehow relates to the bonding social capital that works from the intrinsic matters. Understanding how the community has been built from their history, involving actors, and community goals will be useful to build a narrative development towards appropriation of the project outcomes in participatory approaches.

Community as a value related to a sense of belonging of the community that strengthens certain shared values such as solidarity, coherence, and participatory. It is derived from the loyalty towards mutual relations, recognition of people's contribution, and coherent feelings towards communal goals. Back again to the context of social capital, it is interesting to understand bridging social capital and how it also works to maintain the value within communities. Bridging social capital could work to connect different groups of people with various diversities by reinforcing the commonalities rather than the differences between them. Therefore, incorporating wider actors to obtain positive communal outcomes could lead to a massive action towards sustainable urban development.

The last community senses are an active community, it refers to the sense of belonging within the community where people can be actively involved build 
and rebuild their future in their everyday life. It denotes a fundamental action on how we need a continuous process of engagement to preserve and nurture communal values. Active community is based on the participation of community members, groups and organizations in shaping their community life [Day, 2002]. In relation to linking capital, an active community will not only rely on the horizontal associations, but also leveraging their existence to the vertical connection towards more fundamental changes. In the modern era, it does not enough to just work alone by abandoning the top power authority. In association with participatory, becoming active citizen could deliberate democracy by rupturing their existing attitudes of passivity, silence, ang gain confidence to alter unjust conditions.

On the discussion related to participation, the community posits the main consideration towards participatory approaches. In fact, the notion about community in participatory approaches have been highly criticized due to a basic understanding of the community. For example, in the Participatory Rural Appraisal (PRA), one of the most popular participatory approaches in the developmental context, indicates that communities are seen as homogenous, static and harmonious units where people usually share their needs and benefits [Cooke \& Kothari, 2001].

The critics about PRA emerges due to a simplified understanding of the community that conceals power relations within community itself such as gender, age, class, income, and ethnicity. Therefore, describing a group of people as a community can potentially minimize member's differences in the name of commonalities. In the real condition, community will be more complex and fluid to have a homogenizing term. Internal diversity of community needs to be treated carefully to navigate a community go beyond its potential.

Therefore, community terms should be treated differently as other dimension that represents a social relationship to work together in obtaining a shared goal [Boano \& Kelling, 2013]. A central premise within this notion is a practical motive that can navigate community exceeds their potential. In these regards, we need to acquire capabilities, support, and power in strengthening community to be able to act together. It is also a further step in achieving an active community by setting a common goal as the agency to move together. In terms of building solidarity to move forward, the more members added to the mechanism, the more successful it can be achieved to meet the main goals.

The diversity aspect of the community is visible and needs to be acknowledged. We cannot simply state a community as a single entity without considering the dynamics inside and outside that community. Therefore, the dynamics and tension within community to obtain better negotiations, decisions, and actions will need a continuous process of argumentation to make it happen [Boano \& Kelling, 2013]. It also indicates that the "dissensus" practice on the community is a natural fact and it needs to be treated by the people within the community to open potential and innovation. A conflict, tension, and a dialogue inside the community will be a micro-political practice that makes the participant as an active agent who is involved in the problem [Miessen, 2010]. In the urban development discourse, accommodating "dissensus" should be navigated to a temporary consensus based on the joint visions that happens in particular times.

The actual evidence of an active community, recently, could be seen in a growing determination in Asian cities on informal settlement upgrading that driven by community needs and initiated by grassroots groups [Fitrianto, 2014]. Informal settlement upgrading in urban areas is often in line with slum upgrading. Different to previous major development projects in Asia, the initiatives are globally connected through wider networks of community, activists and professionals. The inclusion of wider networks and institutions is essential in the participatory approaches to get support, exchanging knowledge, and creating alliances. The example can be depicted from the networks of the Asian Coalition for Community Action (ACCA) and also the Slum/Shack Dwellers International (SDI) which operates across the global South [Mitlin \& Satterthwaite, 2012]. Both ACHR and SDI is a coalition of professionals, NGOs and community organizations committed to finding ways to make change in the countries where their work is rooted. Despite strengthening the social capital within communities, wider networks that consist wide variety 
actors and institutions can help to ensure broader solutions in term of sustainable development and empowerment.

Participatory and community engagement needs to be recognized not only as a concept but also treated as a transformative process towards the issue of sustainability in development context. Reconceptualization design and planning as a sociospatial process is also important to act as an approach that not only considers the morphological characteristic of space, but also the social interest in people's everyday life [Cuthbert, 2007]. While challenging the participatory mantra, navigating people-driven processes is preferred rather than an unquestioned adoption of any participation label, so that people will be included in the system of the transformation processes to contribute to the root problem of urbanism in the development world [Boano \& Hunter, 2013].

Moreover, the spatial context in the design discourse is always fundamental. Moving away from a narrow understanding of spatial, the dialogue that comes up from the recognition of socio-spatial within communities will lead to broader possibility outcomes. Participation approach exists to give balance between social and physical structures of the community to obtain a better living place [CAN, 2011]. It could be the medium to contest the established conditions and behaviors within the context while ensuring equality of voices. Based on this notion, community engagement in the context of participatory will be the most important consideration towards better and more promising outcomes in urban development.

\subsection{Participatory Slum Upgrading and Professional Involvement}

In the context of Global South, especially in Asian countries, understanding the capital most likely relates to human settlement, and specifically about housing. Since the 1980s, many countries in Asia were facing urbanization and massive evictions of slums and informal settlements [Boonyabancha, 2010]. At that time, urban slum evictions happened to meet government solution which was a relocation to public high-rise buildings. However, the solution was failed to meet initial government's purpose in achieving better life. Instead, it possibly created a new slum because at the end people decided to leave the buildings and occupied other slum areas. The reason behind this mainly caused by inappropriate strategies of relocation that only worked as a mean of physical matters fulfillment.

Thinking about housing and its functions, it echoes what in 1976 John Turner mentioned about housing as a verb [Turner, 1976]. Housing definition expands its meaning larger than just its basic function as a place to live. It creates other dimensions that Turner mentioned a fundamental shift in housing definition from "what it is" to "what it does". Since then, the notion about selfhelp housing and slum upgrading were escalating and triggered the use of participatory approaches in slum upgrading projects.

The realization of the participatory approaches in slum upgrading often incorporates the role of professionals either through direct or indirect processes. The role of professionals is essential to find a productive balance of negotiations within the community, process of making a decision, as well as stimulating real actions [Boano \& Talocci, 2014]. Through participatory processes, people will be included to the discussion and encouraged to share their ideas as well as their knowledge. Professionals' roles in this matter will be grounded on capacitating and assisting the capability of local community members to be the main catalyst and nexus of the participatory design processes. Capability and dignity in the development acted as central drivers to human's quality life [Sen, 1933]. From the perspective of design, participatory leads the way to find and develop people capabilities [Frediani \& Boano, 2012]. Enabling capacitation and people capabilities will open a possibility of up-scaling participatory outcomes while at the same time ensuring project's sustainability. Therefore, the role of professionals in the participatory design is important to develop people's capabilities in unpacking urban problems both inner and outer communities.

Slums have been defined as mainly those residential areas where dwellings are in any respect unfit for human habitation by reasons of dilapidation, overcrowding, faulty arrangements and designs of such buildings, narrowness or faulty arrangement of streets, lack of ventilation, light, sanitation facilities or 
any combination of these factors which are detrimental to safety, health and morals [Chimankar, 2015].

However, people living in the slum actually have the ability to deal with their condition [Turner, 1976; Boonyabancha, 2010; Fitrianto, 2014], therefore they basically know how to survive in their own environment by using their local knowledge. Through a set of participatory approaches that consider socio-spatial dialogues within the community, professionals should make an intervention that does not affect them to be dependence on, but rather it should be able to make them as the main actor of their own transformation. That is the actual reason why does physical outcomes in the participatory approach usually appears at the end. In the development context, the exercise of designing spaces is indirectly the key of strengthening social capital which is initially embedded in people's everyday life.

Therefore, participation design approaches should be able to develop what already exists in the urban poor rather than changing the behavior [Boonyabancha, et al., 2012]. In the operation, participatory design processes are applying various tools such as city surveys and networking, community mapping, measurement data, self-design exercises, establishing savings groups, meeting and discussions, creating action plans and sharing experiences.

Through this mechanism, we can see the real evidence how the role of the Community Architecture Network (CAN) through Asian Coalition for Community Action (ACCA) programs, and a part of Asian Coalition for Housing Rights (ACHR) are contributing to change the development paradigm of working with the poor through a shared production of space and knowledge [Boano \& Talocci, 2014]. Their practices in various projects of slum upgrading across Asia proved that participatory design with the involvement of society as well as wider variety actors can lead to positive outcomes and play a significant role in terms of project sustainability.

\subsection{Gotong Royong: Indonesian Social Capital Practice}

Twelve case studies have been well-explained in the book written by Putnam, Bowling Alone [2000]. In conclusion, he stated that social capital is naturally a local phenomenon, especially due to its connection between people who already know each other [Putnam, 2000]. Basically, social capital cannot be taken for granted in anywhere, meaning it always depends on the actual context. After considering Bourdieu's notion on the social capital discourse that social capital relates to possession in a durable network [Bourdieu, 1986]. Then, incorporating social capital in the participatory slum upgrading projects can be more complicated. It indicates the need to consider the role of time in the notion of social capital, and apparently it cannot be built instantly. However, the notion of social capital is not something new, and it is a part of human nature to make interactions as well as relations with other people [Oyen, 2002]. For that reason, an investigation of regional and historical perspectives of the social capital is definitely needed before taking it into account as a foundation of participatory approaches.

Indonesia is like most Asian cultures, where people spatially and socially co-live in a community that is related to a network of small clusters [ACHR, 2010]. However, the formal study related to social capital is hardly founded. Without mentioning the terms related to social capital, there are various studies on Indonesian villagers that examine the types and functions of cooperation and human relations [Subejo, 2004]. These relations are founded in numerous types of Indonesian mutual aid, reciprocity, and commonly known as "gotong royong" belief.

Similar to the tension between formal and informal institutions in the discussion of social capital and participation, gotong royong is also facing such an ambivalence condition. In the context of villager economy, gotong royong emerges as unquestioned characters of villagers to engage in the working task related to agriculture or other communal works. Gotong royong is also widely known as an indigenous cultural tradition for Indonesian social life [Bowen, 1986]. Commonly, the relation happens as the strategy of survival that is based on bartering, exchanging, borrowing, and lending goods and services. It has also been applied in terms of achieving either personal or communal mutual relations. Gotong royong relations are usually built upon specific relations such as kinship, 
neighbor-ship, and also friendship [Subejo, 2004]. Therefore, even gotong royong is not perceived as a formal institution structure, the social capital sense through gotong royong belief is potentially embedded in the Indonesian society. The phrase of gotong royong has many definitions, from a mutual assistance to the cooperation within and between social relations. In a simple term, gotong-royong means that solving problems is better to be done together. Although gotong royong is rooted from the Javanese language, there are many versions of gotong royong in another province in Indonesia that using local terms [Mardiasmo \& Barnes, 2015].

In terms of mutual assistance, Bowen explains the nature of reciprocity of Indonesian society based on three bases: labor exchange, general reciprocity, and labor mobilized on the basis of political status [Bowen, 1986]. Labor exchange emerged from the agricultural works such as hoeing, ploughing, planting and harvesting. In a specific period of time, villagers usually do a rotating work in the individual or communal agricultural works. It is usually done by helping each other through exchanging specific workloads in a specific time. For example, one farmer community needs to plant a paddy, the other villager communities will help them without any payment and vice versa.

The second type of mutual assistance in gotong royong terminology is derived from the habit of general reciprocity. It basically refers to the local culture and traditions that have been applied for such a long time in the Indonesian society. In Indonesian context, by its nature, people in the society are obliged to help each other in the events that has been held by their neighbors. The event itself can be varied including marriage event, the death of a relative, or even regular traditional ceremonies. The general reciprocity comprises the basic idea of obligation and eventual return. Furthermore, built upon eventual activities and local traditions, the level of general reciprocity could not be determined in terms of quality and quantity, it is rather unmeasured [Sahlins, 1972].

The last type of mutual assistance in the Indonesian society is mobilized labor on the basis of political status or subordination. It is commonly used by the local government to obtain more attention from society to contribute in public works such as maintaining the irrigation system, cleaning up the environment, securing their neighborhood in the night, and repairing the district road. This type of mutual assistance is often sounded as gotong royong by the government, and it is based on the voluntary willing to work together. The indigenous notion of gotong royong has been recaptured by the state to become a culturalideological instrument that represents the Indonesian character. It is frequently yielded as a slogan of national unity to symbolize various forms of assistance [Bowen, 1986]. Gotong-royong practices have a significant role as well as an important contribution to the Indonesian society life. Therefore, as the socio-cultural ethics of the philosophy of togetherness, gotong-royong can be represented as one of the Indonesian culture elements and it can be perceived as an Indonesian social capital practice.

Considering Putnam's notion related to the main element of social capital: norms (reciprocity), trust, and network, it is actually not a new phenomenon in the Indonesian context. Historically, gotong royong has been grounded in everyday life of Indonesian society whether institutionalized or un-institutionalized. Also, as a part of everyday life of the Indonesian society, it can be considered as a foundation to create communal actions that lead to a successful project. High level of social capital in the society can underpin the successful of community participation and collective action to achieve the common goals [Krishna, 2002].

Building on the mutual relation like kinship, neighbor-ship, and friendship, as well as considering how the mutual assistance is created in the name of gotong royong, we can conclude that gotong royong has been set up as an important asset for the Indonesian society. It comes as a single character that can be used when people are in problem, need a help, ore doing communal projects. Therefore, nurturing gotong royong should be the most important agenda of development in this country especially in framing this believe towards participatory urban development.

\subsection{Community-Based Slum Upgrading in Yogyakarta: A Case Study}

Yogyakarta, is a city in Indonesia with a highly preserving cultural tradition that makes it different to other cities in Indonesia. The sense of gotong royong in Yogyakarta's society is arguably high due to the 
domination of Javanese people who believe in the gotong royong philosophy [Nugraheni \& Yuniarti, 2012]. Framed as a tourism city, Yogyakarta also deals with the problem regarding to poverty. As the tourism growth, the lack access of formal land is inevitable especially after the raise of big capitalist investment. Thus, it caused the poor to squad any available land that mostly becomes a slum area. It also increases the number of informal settlements that predominantly occupy the land near the riverbank. There are three main rivers in Yogyakarta streaming to southern part of the city; Gajahwong on the east side, Code in the middle and Winongo in the west side [Heryanti \& Kingma, 2012]. Around $75 \%$ of the poor lived in these three riverbank areas with the land tenure of Sultan grounds, while remaining settle in some private land and formal kampung. In its rural version, the word kampung literally means village. However, after urbanization era it has also come to mean a poorer neighborhood area contained within a city.

In terms of slum upgrading, actually Yogyakarta has a long story about participatory approaches that involving community inside, especially since a project of slum upgrading in "Kampung Code" received an international award from Aga Khan Award for Architecture in 1992 [Khudori, 2002]. Recently, Kampung Code often becomes a role model of participatory slum upgrading, specifically related to community development that live near riverbank.

Based on actual case of Kampung Kali Code and the spirit of gotong royong, in the late 2010, ArkomJogja (Community Architect in Yogyakarta) was initiated by some community architects and social workers to find solutions regarding to informal settlement issues [Fitrianto, 2014]. They believe that residents should take their own roles in undertaking their problems and challenging their right to the city. A momentum of transformation was in line to the shared initiatives with the ongoing program from ACCA (Asian Coalition for Community Action), a program that was initiated by CAN (Community Architecture Network). Furthermore, this program is also a part of the main organization in the wider context called ACHR (Asian Coalition for Housing Rights) that by now operating in 19 countries, and creating a network with a lot of organizations, communities, academic institutions, and professionals [Boano, 2014].

Since then, they started working together with vulnerable communities in Yogyakarta to solve the problem of land, sanitation, economy, health, and waste management. Working closely with the community that lives along the riverbanks, ArkomJogja assisted 31 communities living in Gajahwong and Winongo riverbanks to establish Paguyuban Kalijawi, a city-wide Federation of savings groups driven by women communities in July 2012. The name of Kalijawi is taken from the combination of two big rivers: Gajahwong and Winongo [Arkomjogja, 2015]. The concept is adopted from Ban Mankoong initiative, which is a successful national slum upgrading program in Thailand [Boonyabancha, 2009]. Thailand's Baan Mankoong collective housing program aims to create the conditions for people who have previously been excluded from secure housing to take the lead in the process of providing their own secure housing through community participatory approaches. Both Ban Mankoong and KaliJawi use a mechanism of community savings to trigger the physical and nonphysical transformations and nurturing sense of social capital within communities.

ArkomJogja helps the community to render themselves as a legible community, and codify the translation of individual into collective endeavors that are visible and precise. A new institutionalism in the discourse of social capital and participation is wellapplied through the making of Paguyuban Kalijawi federation. It could be a medio to practice cooperative relations, exercising norms and sanctions, also reducing the expenses of individuals [Cleaver, 2001]. Built upon the high level of gotong royong philosophy, the operation of ArkomJogja as a "professional", has grounded the design and participatory approach through mapping process, participatory planning, community execution, and saving group scheme. They created possibilities from existing potentials and conditions, and at the same time they stimulate people's capability to tackle their problems. Echoing the spirit of CAN "let people be the solution", ArkomJogja and Paguyuban Kalijawi resounds a fundamental shift in the participatory design approach that included many actors inside and outside the community to work together with same vision and 
communal goals.

The ideas of mutual support from the possession in the wider networks [Bourdieu, 1986] span from exchanged dialogues between communities. It happened through a set of regular meeting between communities. Community meetings and gatherings are not just a place for knowing each other, but it is a medio for a "dissensus" practice happened through dialogues, case studies, and community reports. What makes Paguyuban Kalijawi and ArkomJogja different is the way to maintain the spirit of togetherness as well as nurture social capital through a set of regularly meeting. The meeting itself started from a small group meeting to the large-community networks meeting. It is also supported with the unregularly meetings with other actors outside communities including academicians, professionals, government, other organization both national and international scale.

It has been five years since establishing Paguyuban Kalijawi as a new community platform for the urban transformation in Yogyakarta. In January 2015, the organization accomplished 163 house renewals and renovations, the construction of four community centers, and a lot of basic infrastructural improvements [Arkomjogja, 2015]. We can see that the bonding, bridging, and linking of the social capital in the operation of Paguyuban Kalijawi and ArkomJogja have been applied in completely practical manners.

Like other ACCA projects through a physical upgrading by involving community efforts, the work of ArkomJogja and Kalijawi shifts the logic of slum upgrading from object to subject matters. Paguyuban Kalijawi ties people with the local possibility solutions while at the same time fostering individual and communal capabilities to overcome the problem. In terms of bonding social capital, the creation of new institutions is built based on similar vision, conditions, and spirit of gotong royong. Bridging social capital is applied by connecting the riverside communities in one big organization called Paguyuban Kalijawi, then link it to wider communities from city level to the regional level in the Asian countries. Additionally, in order to find better solutions and create alliances they also make a relation with other institutions, professionals and different actors outside.

The linking of social capital in Kalijawi project was started by presenting their actions to the local government and demanding community based planning for the future plan of Yogyakarta in 2014. In order to create comprehensive changes in perceiving informal settlement upgrading, ArkomJogja and Paguyuban Kalijawi is not only yielding their right through a protest like what others organization do, but they also showed projects and actions that have been done, and more importantly, they presented their capability in term of managing their environment by set of participatory tools like mapping, planning, and organizing. They also initiated a saving group mechanism to the authority and proofed that they could make a change event without government funds. Although not yet accepted as an official approach by the authority but community based participatory upgrading will continue its guerilla, making urban rationality that is continuously rebuilt, renegotiated, and reframed.

\section{CONCLUSION}

This paper shows the trajectory of social capital discourse from bonding, bridging and linking social capital. It spans from just personal benefits in joining a network to communal advantages through horizontal and vertical relations. Gotong Royong that is claimed as Indonesian social capital practice indicates the needs to consider time, people's habit, and regional context before incorporating social capital into actual community actions. Advancing social capital through participatory approaches will lead to a fundamental transformation that can both preserve and nurture its values. A high level of social capital within communities can potentially underpin the successful community participation towards communal goals. Additionally, the role of professionals in the participatory approach is essential to develop people's capabilities in unpacking urban problems both inner and outer communities. Enabling capacitation and people capabilities will open a possibility of up-scaling participatory outcomes while at the same time ensuring project's sustainability.

\section{ACKNOWLEDGEMENT}

The author wishes to thank Indonesian Endowment Fund for Education (LPDP) from Indonesian 
Government for the scholarship support towards author's master study in Building and Urban Design in Development, University College London

\section{REFERENCES}

ACHR. (2010). Community architects in Asia - design with by for people, Bangkok: ACHR.

Archer, D. (2009). Social Capital and Participatory Slum Upgrading in Bangkok, Thailand. Cambridge: Doctoral Dissertation Departement of Land Economy, University of Cambridge.

Arkomjogja. (2015). KALIJAWI Paguyuban Warga Bantaran Sungai Wong dan Winongo Yogyakarta. Yogyakarta: Kali Jawi - Arkomjogja.

Boano, C. (2014). Archiecture of Engagement: Informal urbanism and design ethics. Atlantis Magazine, 24(4), pp. 24-28.

Boano, C. \& Hunter, W. (2013). Recalibrating Critical Design Practice: Excursions through Studio Pedagogy. In: Contested Urbanism in Dharavi: Writings and projects for the resilient city. London: Development Planning Unit, University College London.

Boano, C. \& Kelling, E. (2013). Towards an Architecture of Dissensus: Participatory Urbanism in SouthEast Asia. The Participatory Turn in Urbanism , pp. 41-62.

Boano \& Talocci, G. (2014). The inoperative power architecture and the reclaim of social relevance, London: Studio Magazine.

Boonyabancha, S. (2009). Land for housing the Poor, by the poor: Experiences from the Ban Mankoong Nationwide Slum Upgrading Programme in Thailand. Environment and Urbanization, 21(2),

pp. 309-329.

Boonyabancha, S. (2010). A note from interviews in Bangkok: Community Movements in Asia. In: Design by with for people. Bangkok: Asian Coalition for Housing Rights, pp. 2-4.

Boonyabancha, S., Carcellar, F. \& Kerr, T. (2012). How poor communities are paving their own pathways to freedom. Environment \& Urbanization, 24(2), pp. 441-462.

Bourdieu, P. (1986). The Forms of Capital. In: J. F. Richardson, ed. Handbook of Theory of
Research for Sociology of Education. CT: Greenword Press, pp. 241-58.

Bowen, J. R. (1986). On the political construction of tradition. The Journal of Asian Studies , p. 45.

Butcher, H. (1993). Intoductuon: Some Examples and Definitions. In: H. Butcher, A. Glen, P. Henderson \& J. Smith, eds. Community and Public Policy. London: Pluto Press, pp. 3-21.

CAN. (2011). Comprehensive site planning, Transform community to better living place for all. Bangkok: Community Architect Network .

Chimankar, Digambar A (2016). Urbanization and Condition of Urban Slums in India. Indonesian Journal of Geography,pp. 28-36

Cleaver, F. (2001). Institution, Agency, and the Limitations of Participatory Approaches to Development. In: B. Cooke \& Kothari, Uma, eds. Participation: The New Tyranny?. London: Zen Books Ltd, $\quad$ pp. 36-55.

Coleman, J. (1988). Social Capital in the Creation of Human Capital. American Journal of Sociology, 94(5), pp. 95-121.

Colletta, N. J. \& Cullen, M. L. (2000). The nexus between violent conflict, social capital and social cohesion : case studies from Cambodia and Rwanda. In: C. Grootaert \& T. v. Bastelaer, eds. The Role of Social Capital in Development An Empirical Assessment. Cambridge: Cambridge University Press, pp. 279-309.

Cooke, B. \& Kothari, Uma. (2001). The Case for Participation as Tyranny. In: B. Cooke \& U. Kothari, eds. Participation: The New Tyranny. London: Zed Books Ltd, pp. 1-15.

Cuthbert, A. (2007). Urban design: requiem for an era - review and critique of the lasr 50 years. Urban Design International, Volume 12, pp. 177-223.

Day, P. (2002). Designing Democratic Community Networks: Involving Communities through Civil Participation. In: M. Tanabe, V. D. Besselaar \& T. Ishida, eds. Digital Cities. Berlin: SpringerVerlag, pp. 86-100.

Fitrianto, A. (2014). Securing local ownership, and the architect's dilemma. Claiming the City: Civil Society Mobilisation by the Urban Poor, pp. 95104.

Frediani, A. A. \& Boano, Camilo. (2012). Processes for 
Just Products: The Capability Space of Participatory Design. In: I. Oosterlaken \& Hoven, Van Den J, eds. The Capability Approach, Technology and Design. s.l.:Springer Science+Business Media.

Hickey, S. \& Mohan, Giles. (2004). Towards participation as transformation critical themes and challanges. In: S. Hickey \& G. Mohan, eds. Participation: from tyranny to transformation? Exploring new approaches to participation in development. London: Zed Books Ltd.

Heryanti, Diah N. \& Kingma, Nanette. (2012). Community Based Approach to Assess Flood Risk Perception Along Code River. Indonesian Journal of Geography, pp. 134-149

Jacobs, J. (1961). The Death and Life of Great American Cities. New York: Random House.

Khudori, D. (2002). Towards Freedom Kampung: Developing Society From Its Roots: Learning From Mangunwijaya in Code. Jakarta: Yayasan Pondok Rakyat.

Krishna, A. (2002). Active Social Capita;: Tracing the roots of development and democracy. New York: Columbia University Press.

Mardiasmo, D. \& Barnes , P. (2015). Community Response to Disasters in Indonesia: Gotong Royong a Double Edged-Sword. Brisbane, Queensland University of Technoology, pp. 301307.

Meribe, n. (2012). Indigenous African communication systems and participatory development in rural Africa: The case of a Nigerian village. Sidney, Australian National University, pp. 51-54.

Miessen, M. (2010). The nightmare of participation. Berlin: Strenberg.

Mitlin, D. \& Satterthwaite, David. (2012). Addressing Poverty and Inequality: New Forms of Urban Govenance in Asia. Environment and Urbanization, 24(2), pp. 395-401.

Nugraheni, N. \& Yuniarti, K. (2012). Filosofi Hidup Nrimo dan Gotong Royong dalam Membangkitkan Semangat Hidup Survivor Gempa 27 Mei 2006 di Yogyakarta. Surakarta, Himpunan Psikologi Indonesia.

Oyen, E. (2002). Social Capital Formation as a Poverty Reducing Strategy?. Copenhagen, UNESCO, pp. 11-14.

Putnam, R. (1993). Making Democracy Work: Civic Traditions in Modern Italy. Priceton: Priceton University Press.

Putnam, R. (2000). Bowling Alone. New Yotk : Simon \& Schuster.

Sahlins, M. (1972). Stone Age Economics. New York: Aldine.

Scott, J. C. (1998). Address to the Seventh Annual Conference of the International Association for the Study of Common Property, Vancouver: s.n.

Sen, A. (1933). Development As Freedom. New York: Anchir Books.

Serageldin. (1996). Sustainability as Opportunity and the Problem of Social Capital. Brown Journal of World Affairs, pp. 187-203.

Subejo. (2004). The Role of Social Capital in Economic Development. Jurnal Agro Ekonomi, 11(1), pp. 77-86.

Turner, J. F. C. (1976). Housing By People Towards Autonomy in Building environments. New York: Pantheon Books.

Uphoff, N. (2000). Understanding social capital: learning from the analysis and experience of participation. In: P. Dasgupta \& I. Serageldin, eds. Social Capital A Multifaced Perspective. New York: Cornell University Press, pp. 215249.

Woolcock, M. (2001). The place of social capital in understanding social and economic outcomes. Canadian Journal of Policy Research, 2(1), pp. 1-35.

Woolcock, M. (2002). Social Capital in Theory and Practice: Reducing Poverty by Building Partnerships between States, Markets and Civil Society. Copenhagen, UNESCO, pp. 20-44.

World Bank. (2000). World Development Report 1999/2000: Entering the 21st Century, New York: Oxford University Press. 